\title{
CDIAKRONIKA
}

Vol. 17 No. 2 Th. 2017 p: 153-162

ISSN: 1411-1764 (Print) | 2620-9446 (Online)

http://diakronika.ppj.unp.ac.id

\section{Pembelajaran Sejarah Bermuatan Lokal Pada Sekolah Menengah Atas (Sma) Di Sumatera Barat}

\author{
Etmi Hardi \\ etmihardi@yahoo.co.id \\ Universitas Negeri Padang
}

\begin{abstract}
Indigenous School Education Officer for Civil-directed, School Opleiding voor Inlandsche Ambtenaren (OSVIA) in Serang Banten years 1900-1927. This research is based on a system of government that the Dutch East Indies in the program directed by the Government is required to be able to perform administrative tasks in the province but because of the high officials who have to come from the Netherlands to the Dutch government established a school to meet educational officials natives in the province. The purpose writers to learn the system of government in the province with the native elite-modern with the traditional school as a condition for becoming a regent. The method that I use the method of Historical done through several stages, namely: (1) Heuristics, (2) criticism, (3) interpretation, (4) Historiography. While the techniques used to obtain data through library research by studying and analyzing various resource books, newspapers, interviews and archival materials related to the issues discussed. The results reveal that the purpose of recruitment administration in Banten just to get the officer natives are very cheap and the Dutch government considers important role for indigenous political elite bureaucracy native is an intermediary between the government and the people using its traditional authority. So the Dutch government established a school to become an administrative officer at the school named Banten OSVIA. After the establishment of the school in Serang Banten OSVIA traditional governance with the pedigree of the king replaced by a modern system which breeds not be the main requirement to be governor, but education has to be provided to the regents, in which a minimum standard of education graduates OSVIA and able to speak Dutch.

Thus the author can give lessons to the community and fellow students with thesis title so that I can learn a transitional government would be traditional-modern in Banten after the arrival of the Dutch.
\end{abstract}

Keyword : School, Regent, Inlandsche Ambtenaren 
Abstrak

Petugas Pendidikan Sekolah Adat ditujukan untuk Sipil, Sekolah School Opleiding voor Inlandsche Ambtenaren (OSVIA) di Serang Banten tahun 1900-1927. Penelitian ini didasarkan pada sistem pemerintahan bahwa Hindia Belanda dalam program yang diarahkan oleh Pemerintah dituntut untuk dapat melakukan tugas-tugas administratif di provinsi tersebut tetapi karena pejabat tinggi yang harus datang dari Belanda ke pemerintah Belanda mendirikan sekolah untuk bertemu pejabat pendidikan pribumi di provinsi ini. Tujuan penulis untuk mempelajari sistem pemerintahan di provinsi dengan elit asli-modern dengan sekolah tradisional sebagai syarat untuk menjadi bupati. Metode yang saya gunakan metode Historical dilakukan melalui beberapa tahapan, yaitu: (1) Heuristik, (2) kritik, (3) interpretasi, (4) Historiografi. Sedangkan teknik yang digunakan untuk memperoleh data melalui penelitian pustaka dengan mempelajari dan menganalisis berbagai buku sumber, surat kabar, wawancara dan materi arsip terkait dengan masalah yang dibahas. Hasil penelitian mengungkapkan bahwa tujuan administrasi rekrutmen di Banten hanya untuk mendapatkan pegawai pribumi yang sangat murah dan pemerintah Belanda menganggap peran penting birokrasi elit politik pribumi asli adalah perantara antara pemerintah dan masyarakat dengan menggunakan otoritas tradisionalnya. Maka pemerintah Belanda mendirikan sekolah untuk menjadi petugas administrasi di sekolah bernama Banten OSVIA. Setelah pendirian sekolah di Serang Banten OSVIA pemerintahan tradisional dengan silsilah raja digantikan oleh sistem modern yang berkembang biak tidak menjadi syarat utama untuk menjadi gubernur, tetapi pendidikan harus diberikan kepada bupati, di mana standar minimum lulusan pendidikan OSVIA dan mampu berbahasa Belanda. Dengan demikian penulis dapat memberikan pelajaran kepada masyarakat dan rekan-rekan siswa dengan judul skripsi sehingga saya dapat belajar pemerintahan transisi akan menjadi tradisional-modern di Banten setelah kedatangan Belanda.

Kata Kunci : Sekolah, Bupati, Pejabat Asli. 


\section{Pendahuluan}

Pendidikan merupakan suatu kegiatan rekayasa untuk mengendalikan pembelajaran guna mencapai tujuan yang direncanakan secara efektif dan efisien. Dalam proses rekayasa tersebut peranan pengajar sangat penting, karena merupakan kegiatan yang dilakukan oleh guru untuk mentransfer pengetahuan, keterampilan dan nilai pada siswa sehingga apa yang ditransfer memiliki makna bagi dirinya sendiri serta masyarakat (Zamroni, 2001).

Transfer ilmu biasanya dilakukan guru dalam proses pembelajaran, baik di dalam, maupun di luar kelas. Oleh sebab itu sebelum proses pembelajaran dilakukan seorang guru harus melakukan berbagai persiapan, menyangkut tiga hal pokok. Pertama, tentang apa yang akan diajarkan. Kedua, bagaimana cara mengajarkan sesuatu sehingga bisa mencapai tujuannya. Ketiga, mengetahui bahwa yang diajarkan itu dapat mencapai sasarannya (Wirawan, 2002). Persoalan pertama berkaitan dengan tujuan pembelajaran dan materi yang akan diajarkan. Sementara, persoalan kedua menyangkut strategi, model, metode, dan alat yang akan digunakan. Persoalan ketiga menyangkut evaluasi yang dilakukan untuk mengukur capaian pembelajaran.

Dengan adanya persiapan yang matang sebelum mengajar, maka proses pembelajaran akan dapat berlangsung secara baik dan lancer tanpa ada hambatan yang berarti. Di samping itu, pembelajaran menjadi lebih terarah dan siswa lebih mudah untuk mencerna informasi atau materi pembelajaran. Menurut Sardiman (2001) guru adalah salah satu komponen manusia dalam proses belajar mengajar. Guru berperan penting dalam usaha pembentukan sumber daya manusia yang potensial di dalam kebutuhan pembangunan. Oleh karena itu, guru merupakan salah satu unsur penting yang harus berperan serta secara aktif dan menempatkan kedudukan sebagai tenaga profesional sesuai dengan tuntutan kebutuhan masyarakat yang makin kompleks.

Dalam menyusun persiapan mengajar berupa Silabus dan Rencana Pelaksanaan Pembelajaran (RPP), seorang guru harus menyiapkan materi pelajaran yang akan diajarkan. Sebab pada dasarnya materi merupakan salah satu sasaran tujuan akhir pembelajaran. Dalam Kurikulum 2013 (K-13) materi pembelajaran dikembangkan dari kompetensi (kompetensi inti dan kompetensi dasar) yang sudah disiapkan sedemikian rupa oleh perancang kurikulum.

Pembelajaran sejarah adalah bersifat unik dan khas, karena sejarah berorientasi kepada masa lalu. Dalam arti kata, sejarah mempelajari peristiwa dan kejadian-kejadian masa lalu. Oleh sebab itu fakta fakta sejarah selalu berada di masa lampau, tidak pada hari ini, atau masa depan. Dalam kondisi seperti itu tentunya tidak mudah bagi seorang guru mengajarkan sejarah 
sehingga dengan dapat mudah dipahami dan dimengerti oleh siswa. Apalagi tujuan pembelajaran tidak hanya terfokus pada transfer pengetahuan (knowledge), tetapi juga pada nilai nilai (afektif) yang berguna pada kehidupan hari ini dan nanti.

Dalam pembelajaran sejarah seorang guru harus mampu mendekatkan anak didik dengan objek pembelajaran, dalam hal ini tentunya peristiwa, yang dipelajarinya. Contoh-contoh fakta sebaiknya dicari dari fenomena yang berada di sekitar mereka. Konsep dibangun serta dikembang berdasarkan realitas masa lalu yang juga berada di sekitar mereka. Dengan cara seperti itu akan lebih memudahkan mereka dalam mempelajari dan memaknai peristiwa atau kejadian masa lampau. Di sinilah pentingnya materi sejarah yang bernuansa muatan lokal diberikan sebagai penunjang materi esensial yang ada dalam kurikulum.

Tulisan ini berangkat dari kenyataan bahwa para guru sejarah tingkat SMA di Sumatera Barat masih amat jarang memasukkan materi sejarah yang bersifat lokal Sumatera Barat dalam proses pembelajaran di dalam kelas. Kenyataan seperti ini diperoleh ketika berhubungan langsung dengan para guru sejarah SMA di Sumatera Barat, baik dalam kegiatan MGMP (Musyawarah Guru Mata pelajaran), seminar dan diskusi ilmiah, atau pembimbingan Praktek Lapangan Kependidikan (PLK) mahasiswa. Dalam kurikulum KTSP dan K-13 yang diterapkan di berbagai sekolah di Indonesia dewasa ini mengharuskan adanya integrasi materi pelajaran muatan lokal ke dalam materi pelajaran. Mengapa hal ini terjadi? Apakah ini disebabkan kemalasan (mentalitas) para guru sejarah, ataukah karena ketidakmampuan guru sejarah untuk mengolah materi sejarah yang bersifat lokal untuk diintegrasikan ke dalam Kompetensi Kompetensi yang sudah ditentukan dalam kurikulum nasional? Tulisan singkat ini ingin menjawab tiga pokok persoalan. Pertama, mengapa materi sejarah yang bernuansa muatan lokal penting dimasukkan ke dalam pembelajaran sejarah? Kedua materi-materi sejarah lokal seperti apakah yang mesti diintegrasikan ke dalam materi pelajaran sejarah yang sudah bersifat nasional sebagaimana yang tercantum dalam kurikulum? Ketiga, sudah sejauh apa pengetahuan dan pemahaman para guru sejarah tingkat SMA di Sumatera Barat terhadap materi sejarah bermuatan lokal?

\section{Hasil Dan Pembahasan}

Dimasukkannya unsur muatan lokal dalam kurikulum pada hakikatnya tidak lepas dari realitas bahwa Indonesia memiliki keberagaman dalam segala hal, terlebih untuk adat istiadat, kesenian, tata cara, tata krama pergaulan, bahasa dan pola-pola kehidupan yang turun temurun dari nenek moyang 
bangsa Indonesia. Semua itu mesti menjadi rujukan penting bagi anak didik agar tidak kehilangan ciri khas dan jati dirinya. Upaya menjaga kekhasan ini dapat dilakukan oleh guru sejarah melalui penambahan materi sejarah dengan muatan lokal, mulai dari tingkat Sekolah Dasar (SD), Sekolah Menengah Pertama (SMP), hingga Sekolah Menengah Atas (SMA).

Dengan muatan lokal guru sejarah dapat mengoptimalkan capaian pengetahuan dan pemahaman sejarah peserta didik, serta meningkatkan kesadaran sejarah mereka. Pembelajaran sejarah dapat diperkaya dengan berbagai peristiwa sejarah yang terjadi di sekitar siswa. Lokalitas di sekitar siswa mengandung berbagai peristiwa sejarah yang amat menarik dan kaya untuk dipelajari. Apalagi setiap daerah di Indonesia mengalami perjalanan waktu sejak zaman prasejarah hingga periode kontemporer. Perjalanan itu terekam di dalam berbagai peristiwa sejarah, yang bukti-buktinya tersebar hampir di seluruh daerah di Indonesia, baik dalam bentuk tulisan, lisan, maupun benda. Dapat dikatakan masing masing daerah memiliki jejak sejarahnya sendiri-sendiri yang berbeda satu sama lain.

Muatan lokal juga akan membuat pelajaran sejarah lebih menarik bagi siswa karena fakta-fakta peristiwa sejarah sangat dekat dengan lingkungan mereka, sehingga memudahkan mereka untuk mempelajarinya. Kondisi nyata di sekitar siswa dapat digunakan oleh guru sebagai cara untuk menggambarkan dan mengantarkan suatu peristiwa sejarah serta memahami berbagai isu sosial yang ada dalam masyarakat. Penelitian Supriatna (2015) telah membuktikan bahwa muatan lokal sangat efektif dalam meningkatkan kemampuan siswa dalam memahami berbagai isu sosial yang ada di sekitarnya.

Demikian pentingnya muatan lokal, hingga di dalam pengembangan kurikulum di Indonesia semenjak dari dulu lalu hingga Kurikulum 2013 (K-13) diimplementasikan pemerintah selalu turut mempertimbangkan keberadaannya. Keberadaan muatan lokal dalam kurikulum telah diatur dalam Surat Keputusan Menteri Pendidikan dan Kebudayaan Republik Indonesia Nomor 0412/U/1987 tanggal 11 Juli 1987. Pelaksanaannya dijabarkan berdasarkan Keputusan Direktur Jenderal Pendidikan Dasar dan Menengah Nomor 173/C/Kep/M/ 87 tanggal 7 Oktober tahun 1987. Menurut surat keputusan tersebut, yang dimaksud dengan muatan lokal adalah program pendidikan dimana isi dan media penyampaiannya dikaitkan dengan lingkungan alam dan lingkungan budaya, serta kebutuhan daerah dan wajib dipelajari oleh murid di daerah tersebut.

Sementara dalam Kurikulum 2013 muatan lokal diatur dalam Permen (2014). Dalam Permen tersebut dikatakan bahwa muatan lokal merupakan bahan kajian atau mata pelajaran pada satuan pendidikan (SD, SMP/MTs, dan 
SMA/MA) yang berisi muatan dan proses pembelajaran tentang potensi dan keunikan lokal yang dimaksudkan untuk membentuk pemahaman peserta didik terhadap keunggulan dan kearifan di daerah tempat tinggalnya Permen (2014, pasal 1 dan 2 ). Secara materi muatan lokal boleh menajadi mata pelajaran tersendiri atau diintegrasikan ke dalam mata pelajaran tertentu, seperti sejarah

Materi sejarah lokal, termasuk sejarah lokal Sumatera barat, dapat memperkaya berbagai peristiwa dan fakta sejarah yang berada pada tingkat nasional. Hal ini disebabkan buku buku teks pendukung kurikulum, baik yang dikeluarkan resmi oleh Kementerian Pendidikan dan Kebudayaan, maupun yang diproduksi oleh para penerbit, amat jarang memasukkan unsur unsur lokal ini ke dalam buku buku yang mereka produksi. Hampir dipastikan materi sejarah yang ditampilkan lebih bersifat nasional, bahkan cenderung "Jawa Centris". Sebagai contoh materi tentang Kehidupan Zaman Pra Aksara lebih banyak menampilkan peristiwa dan kejadian kejadian yang berada di daeraj Jawa, dan sama sekali tidak membicarakan lokal Sumatera Barat. Demikian juga pembahasan tentang Peristiwa Sekitar Proklamasi dan masa Perang Kemerdekaan (1945-1949), hampir tidak memasukkan peristiwa peristiwa yang berlangsung di tingkat lokal Sumatera Barat. Padahal Sumatera Barat memiliki kisah dan ceritanya sendiri tentang peristiwa tersebut.

Secara teoritis pemahaman siswa terhadap materi sejarah yang dipelajarinya akan lebih mudah jika apa yang dipelajarinya itu berada dekat dengan lingkungan dimana ia berada. Sebab ada "kedekatan emosional" antara ia dengan objek yang dipelajaronya. Di samping itu ia juga bisa diajak untuk menyaksikan ataupun menemukan bukti bukti dari peristiwa dan fakta sejarah yang dipelajari. Dengan demikian pembelajaran sejarah yang penuh makna (the meaningfull) dapat diberikan pada siswa, dimana masa lalu tidak hanya dipelajari untuk masa lalu, tetapi juga untuk kepentingan hari ini, bahkan masa depan.

Pendidikan merupakan proses budaya yang secara terus menerus senantiasa mengalami perubahan sejalan dengan perkembangan jiwa zaman (zeitgeist). Salah satunya adalah perubahan otoritas sistem pendidikan sentralisasi ke desentralisasi. Format otonomi daerah memberi ruang dan kesempatan luas kepada para guru untuk mengembangkan nilai-nilai sosial dan budaya yang bersifat lokal.

Dalam Peraturan Pemerintah No. 19 Tahun 2005 sebagai pijakan pelaksanaan Kurikulum KTSP (Kurikulum Tingkat Satuan Pendidikan), muatan lokal diartikan sebagai kegiatan kurikuler yang bertujuan untuk mengembangkan kompetensi yang disesuaikan dengan ciri khas dan potensi 
daerah, termasuk keunggulan daerah, yang materinya tidak dapat dikelompokkan ke dalam mata pelajaran yang ada. Lebih lanjut dalam Permen No. 79 (2014) dinyatakan bahwa muatan lokal merupakan bahan kajian atau mata pelajaran pada satuan pendidikan yang berisi muatan dan proses pembelajaran tentang potensi dan keunikan lokal yang dimaksudkan untuk membentuk pemahaman peserta didik terhadap keunggulan dan kearifan di daerah tempat tinggalnya. Dengan demikian, baik KTSP ataupun K-13 yang diberlakukan di berbagai tingkat pendidikan di Indonesia dewasa ini mewajibkan adanya muatan lokal dalam kurikulum, yang pelaksanaannya diserahkan pada masing masing daerah (desentralisasi).

Khusus untuk mata pelajaran sejarah, materi muatan lokal dapat dikembangkan dan diramu oleh guru dari materi sejarah lokal. Lantas apa batasan dari lokal itu sendiri? Dalam hal ini memang banyak penafsiran yang diberikan para sejarawan terhadap sejarah lokal. Akan tetapi dalam konvensi Pedoman Penulisan Sejarah Lokal yang dikeluarkan Direktorat Nilai Sejarah Departemen Kebudayaan dan Pariwisata Tahun 2006 yang lalu dinyatakan bahwa sejarah lokal itu haruslah berada di bawah sejarah nasional dalam pengertian wilayah, bukan ideologis (rumusan hasil seminar penulisan sejarah lokal di Bukittinggi, Tahun 2006). Lokalitas disini dapat berbentuk propinsi, kabupaten, kecamatan, desa, atau merujuk kepada etnisitas tertentu (Hardi, 2015a). Secara teoritis batas-batas lokal dapat ditentukan oleh peneliti atau sejarawan, namun skop sejarah lokal harus lebih kecil dari skop nasional, ataupun regional (Abdullah, 2006).

Berdasarkan pengertian-pengertian di atas, menurut hemat penulis muatan sejarah lokal sebagai suplemen dari sejarah nasional sebaiknya berada pada tingkat provinsi. Dalam arti materi-materi yang dimasukkan ke dalam sejarah lokal itu adalah peristiwa atau kejadian kejadian "penting" yang berada pada tingkat provinsi. Hal yang lebih penting lagi adalah materi-materi sejarah local tersebut bisa menunjukkan "keunggulan" lokal dalam panggung sejarah nasional secara keseluruhan, di samping makin memperkuat identitas nasional dan integrasi nasional. Dengan demikian muatan materi sejarah lokal Sumatera Barat mesti digali dari berbagai peristiwa penting yang terjadi di wilayah Sumatera Barat sejak pada masa lalu, mulai dari periode masa Praaksara hingga periode Sejarah Kontemporer.

Mempelajari sejarah lokal untuk Sekolah Menengah Atas (SMA) tentunya berbeda dengan sejarah nasional (Sejarah Indonesia) sebagaimana yang tercantum dalam kurikulum. Materi Sejarah Indonesia mulai dari Kelas $X$ hingga kelas XII sesuai KD-KD yang digariskan dalam kurikulum sudah tersedia dalam berbagai literatur, baik dalam bentuk buku teks yang beredar di pasaran, maupun "buku babon" (buku standar) yang diterbitkan oleh pemerintah, 
seperti Sejarah Nasional Indonesia (jilid I sampai VI). Berbeda halnya dengan sejarah lokal yang literaturnya masih "berserakan" dalam berbagai buku dan karya penelitian, baik hasil kerja sejarawan, peminat sejarah, maupun mahasiswa. Dalam hal ini guru sejarah mesti mengumpulkan dan meramu semua literatur itu untuk dapat digunakan dalam proses pembelajaran, sehingga menjadi kurikulum yang bermuatan lokal. Disini dibutuhkan profesionalisme guru sejarah sebagai seorang tenaga pendidik. Jika guru sejarah tidak kreatif dan inovatif dalam mengolah berbagai literatur sejarah lokal untuk dijadikan muatan lokal, maka diyakini pembelajaran dalam kurikulum sejarah yang bermuatan lokal tidak akan pernah dapat terlaksana.

Strategi yang dapat dilakukan guru sejarah dalam mengembangkan materi pelajaran sejarah lokal Sumatera Barat adalah dengan tetap berpedoman pada KD-KD yang ada dalam kurikulum, misalnya Kurikulum-13. Para guru sejarah melakukan analisis terhadap KD-KD mata pelajaran sejarah dan menentukan pada KD mana yang ada muatan materi sejarah lokalnya, serta di KD yang mana yang tidak ada muatan lokalnya. Analisis KD tentunya harus dilakukan secara keseluruhan, mulai dari kelas $X$ hingga kelas XII. Setelah dilakukan analisis KD barulah para guru sejarah menentukan literatur apakah yang bisa digunakan untuk melengkapi materi muatan lokal itu, dan dimanakah bisa didapatkan? Untuk menentukan ini para guru sejarah dapat melakukan penelusuran bibliografi, atau bertanya pada para "pakar" sejarah.

Berdasrkan penelitian yang penulis lakukan dengan teman-teman di Sumatera Barat tentang topik ini diperoleh gambaran sementara bahwa pembelajaran sejarah yang dilakukan masih cenderung mengabaikan muatan lokal. Para guru sejarah masih terfokus mengajarkan sejarah Indonesia sebagaimana adanya, seperti yang tercantum dalam kurikulum standar (KTSP atau K-13). Para guru sejarah masih terjebak dalam pemahaman materi sejarah secara literlek sebagaimana yang tertulis dalam buku teks resmi (buku babon), maupun buku teks yang diproduksi oleh banyak penerbit, tanpa kreatifitas untuk mengembangkannya. Hasil penelitian (Hardi, 2015b)menunjukkan guru sejarah umumnya hanya mengambil dan mengembangkan materi sejarah dari buku teks yang beredar di pasaran, seperti buku terbitan Yudistira, Erlanggga, dan Exist. Hampir dipastikan buku buku teks yang diproduksi oleh penerbit tersebut tidak memasukkan muatan lokal ke dalamnya, karena buku teks tersebut dirancang untuk kebutuhan para guru sejarah di seluruh wilayah Indonesia.

Setelah ditelusuri lebih lanjut ternyata fenomena seperti di atas terjadi bukan disebabkan oleh sikap apatis atau kemalasan para guru, tetapi ada dua faktor. Pertama, kekurangpahaman para guru tentang konsep sejarah lokal, 
serta peristiwa-peristiwa seperti apakah yang pantas dimasukkan ke dalam suplemen sejarah lokal Sumatera Barat. Kedua, keterbatasan sumber yang dapat digunakan untuk merekonstruksi berbagai peristiwa yang terjadi di tingkat lokal Sumatera Barat untuk kemudian diintegrasikan ke dalam materi sejarah Indonesia secara keseluruhan (Hardi, 2017).

Batasan lokalitas masih menjadi kebingungan dan kerancuan dari para guru sejarah. Sebagai contoh guru sejarah di Kabupaten Agam melihat lokal secara sempit, yaitu peristiwa peristiwa sejarah yang berada di sekitar wilayah itu saja, misalnya tentang Perang Mangopoh. Kemudian guru guru sejarah di Kabupaten Pasaman juga bepikiran seperti itu, sehingga cenderung memasukkan peristiwa-peristiwa yang berlangsung di sekitar kabupaten itu saja, misalnya tentang Gerakan Paderi yang dipimpin oleh Tuanku Rao.

Di samping itu bahan-bahan yang membicarakan sejarah lokal di Sumatera Barat secara menyeluruh hampir tidak ada. Kalaupun ada bahan-bahan tersebut lebih bersifat parsial dan fragmentaris, sehingga menyulitkan guru untuk menggunakan dan mengolahnya. Belum ditemukan satu buku ataupun literatur standar yang bersifat komprehensif yang dapat dijadikan acuan oleh para guru dalam menyusun materi sejarah yang bermuatan lokal Sumatera Barat. Kondisi seperti ini menjadi salah satu alasan belum terselenggaranya pembelajaran sejarah yang memasukkan unsur peristiwa- peristiwa lokal ke dalam sejarah nasional (Sejarah Indonesia).

\section{Kesimpulan}

Pembelajaran sejarah bermuatan lokal amat penting dilakukan oleh para guru di sekolah-sekolah, sebab peristiwa peristiwa yang berlangsung di tingkat lokal dapat mendekatkan siswa dengan objek yang dipelajarinya, sehingga memudahkan siswa untuk memahami materi pelajaran sejarah yang dipelajarinya. Untuk memasukkan unsur-unsur lokal ke dalam pembelajaran sejarah diperlukan usaha yang kreatif dan inovatif dari para guru sejarah. Hal ini tentunya menjadi tantangan tersendiri bagi para guru sejarah yang mengajar di tingkat SMA pada masa datang.

Para guru harus menyadari bahwa pengajaran sejarah tetap memiliki peran besar dalam membentuk karakter bangsa, serta pembinaan integritas generasi bangsa. Sebagaimana dinyatakan oleh Sartono Kartodirdjo bahwa sejarah adalah sebagai sarana pembentukan identitas diri suatu bangsa. Salah satu cara yang dapat dilakukan untuk mencapai tujuan itu ialah dengan mengintegrasikan materi sejarah bermuatan lokal dengan sejarah nasional (Sejarah Indonesia). 


\section{Daftar Rujukan}

Abdullah, T. dkk. (2006). Pedoman Penulisan Sejarah Lokal. Jakarta:

Direktorat Nilai Sejarah dan Purbakala Departemen Kebudayaan dan Pariwisata.

Hardi, E. (2015a). Sejarah Lokal: Konsep dan Aplikasi. Padang: UNP.

Hardi, E. (2017). Wawancara dengan sejumlah guru sejarah di Kota Padang, Kabuopaten Agam, dan Kabupaten Pasaman.

Hardi, E. dkk. (2015b). Penggunaan Buku Teks Sejarah di Kalangan Guru-Guru SMA Kabupaten Pasaman: Studi tentang Pemilihan dan Pemanfaatannya dalam Proses Pembelajaran. Padang.

Permen. Peraturan Menteri Pendidikan Nasional Nomor 79 Tahun 2014 tentang Muatan Lokal Kurikulum 2013. , (2014).

Sardiman, A. M. (2001). Interaksi dan Motivasi dalam belajar Mengajar. Jakarta: Raja Grafindo Persada.

Supriatna, N. (2015). Konstruksi Pembelajaran Sejarah Lokal untuk Memahami Isu-Isu Sosial. Historia, 11 (VI).

Wirawan, S. (2002). Optimalisasi Kecerdasan Ganda dalam Era Informasi dan Globalisasi. Yogjakarta: PPS UNY.

Zamroni, P. U. D. (2001). Tantangan Menuju Civil Society. Yogyakarta: BIGRAF Publishing. 